\title{
How long is long enough? Decreasing effects in Aedes aegypti larval mortality by plant extracts over time
}

Quanto tempo é tempo suficiente? Redução dos efeitos na mortalidade larval de Aedes aegypti por extratos de plantas ao longo do tempo

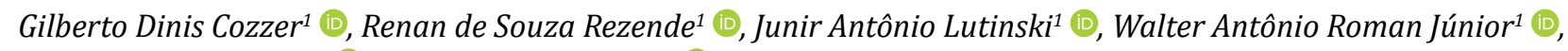
Maria Assunta Busato ${ }^{1}$ (D), Daniel Albeny Simões ${ }^{2}$ (D)

\section{A B S T R A C T}

Aedes aegypti has overcome all kinds of mosquito control attempts over the last century. Strategies for population control resorts to the use of synthetic insecticides, which can lead to problems like human intoxication and environmental contamination. The effects of Bacillus thuringiensis var. israelensis (Bti), Ilex paraguariensis (yerba mate), and Ilex theezans (caúna herb) extracts against A. aegypti larvae were evaluated. The bioassays were conducted under controlled laboratory conditions of temperature $\left(27 \pm 3^{\circ} \mathrm{C}\right)$ and photoperiod (12 h). Hydroalcoholic extract of the leaves of $I$. theezans displayed better residual effect compared to the aqueous extract of $I$. paraguariensis fruits. The strongest residual effect of I. theezans was probably due to the presence of certain chemicals in its leaves, such as coumarins, hemolytic saponins, and cyanogenic glucosides, which were absent in 1 . paraguariensis. The results herein contributed to the prospection of natural insecticides and opened the possibility for subsequent studies on the use of plant extracts in field situations in a short-time scale.

Keywords: dengue; vector control; inseticide; entomology; mate herb.

\section{RE S U M 0}

Aedes aegypti superou todos os tipos de tentativas de controle do mosquito pelo homem no último século. Estratégias para controle populacional recorrem ao uso de inseticidas sintéticos, que podem levar a problemas como intoxicação humana e contaminação ambiental. Foram avaliados os efeitos de Bacillus thuringiensis var. israelensis (Bti), extratos de llex paraguariensis (erva-mate) e Ilex theezans (erva-caúna) contra a mortalidade de larvas de $A$. aegypti. Os bioensaios foram conduzidos sob condições laboratoriais controladas de temperatura ( $27 \pm$ $3^{\circ} \mathrm{C}$ ) e fotoperíodo ( $12 \mathrm{~h}$ ). $O$ extrato hidroalcoólico de folhas de $\mathrm{l}$. theezans apresentou melhor efeito residual quando comparado ao extrato aquoso de frutos de $I$. paraguariensis. O efeito residual mais forte de $I$. theezans provavelmente ocorreu devido à presença de substâncias químicas em suas folhas, tais como cumarinas, saponinas hemolíticas e glicosídeos cianogênicos, ausentes em $l$. paraguariensis. Nossos resultados contribuíram para a prospeç̧ão de inseticidas naturais e abriram a possibilidade de estudos subsequentes sobre o uso de extratos vegetais em situações de campo em um curto espaço de tempo.

Palavras-chave: dengue; controle vetorial; inseticida; entomologia; erva-mate.

\footnotetext{
${ }^{1}$ Universidade Comunitária da Região de Chapecó - Chapecó (SC), Brazil.

${ }^{2}$ BioVectors Soluções em Controle de Vetores - Chapecó (SC), Brazil.

Correspondence address: Daniel Albeny Simões - Rua Marechal Borman, 317D - Centro - CEP: 89801-050 - Chapecó (SC), Brazil E-mail: danielalbeny@gmail.com.

Conflicts of interest: the authors declare there are no conflicts of interest.

Funding source: Universidade Comunitária da Região de Chapecó.
}

Received on: 05/25/2020. Accepted on: 10/27/2020.

https://doi.org/10.5327/Z21769478806

This is an open access article distributed under the terms of the Creative Commons license. 


\section{Introduction}

Over the last century, the mosquito Aedes aegypti (Linnaeus, 1762) has overcome all mosquito control attempts. A. aegypti females are well known by their capacity of naturally and/or under laboratory conditions replicate and transmit over 100 kinds of viruses (Weaver and Reisen, 2010). As an example, the viruses of Dengue, Chikungunya, Zika, and, most recently, the Mayaro (Weaver and Reisen, 2010) virus can be listed in Brazil, which represent a real threat to public health (Lopes et al., 2014). Therefore, its medical importance requires the population control of this species to reduce virus transmission and, consequently, its epidemic status. Although several chemical and natural products have been extensively used on attempts to reduce the population of adults and larvae (Liu, 2015; Apaire-Marchais et al., 2016), adequate mosquito control is not even close to become true, especially due to the genetic resistance selectivity because of the incorrect use of natural products and chemicals (Sun et al., 2019). As a consequence, the most effective disease prevention method still focus on targeting the mosquito population by eliminating mosquito breeding places (Brasil, 2002).

A very promising field for reducing the mosquito population is to focus on mosquito control strategies that target immature aquatic stages, when the insect is more vulnerable (Brasil, 2001; Crivelenti et al., 2010). For this purpose, the use of synthetic insecticides is well known for its efficacy, causing mosquito larval mortality (Busato et al., 2015; Govindarajan et al., 2018). However, those chemicals might affect humans, resulting in intoxication and environmental contamination, and affecting biodiversity $(\mathrm{Bu}-$ sato et al., 2015; Tahir et al., 2015; Baskar et al., 2018; Govindarajan et al., 2018). Regarding the environment, the continuous use of synthetic insecticides may present undesirable effects, such as the long-term permanence in the environment, selection of resistant populations, and the appearance of new pests (Tahir et al., 2015; Baskar et al., 2018; Govindarajan et al., 2018). As to human health, the presence of such synthetic chemicals on the environment can cause neurological damage and is associated with a wide range of symptoms, with significant deficits in the nervous system function (Araújo et al., 2007).

Alternatively to the use of synthetic chemicals, biological control plays an important role on mosquito management (Zara et al., 2016; Coelho et al., 2017). The use of bacteria spores as a mosquito larvicide has stood out among the several components that are part of mosquito-integrated management programs (Zara et al., 2016). Over the last decade, the use of inactivated spores of the bacteria Bacillus thuringiensis var. israelensis (Bti), spread in the water of mosquito breeding places, has met the expected results, reaching mortality rates above 99\% (Soares-da-Silva et al., 2017; Nakazawa et al., 2020). Additionally, during the last few years, plant-derived compounds have been extensively used as an alternative method for controlling mosquitoes, not only because this is a new insecticidal agent, but also because it has been described as being environmentally friendly (Gomes et al., 2016; Guarda et al., 2016; Knakiewicz et al., 2016; Rosa et al., 2016). The use of natural insecticides has some advantages over traditional synthetic products, because natural products are potentially less toxic to the environment. Environmentally-friendly compounds are less concentrated, have faster degradation, and are specific to certain insect groups, resulting in less occupational exposure and less environmental pollution (Krinski et al., 2014).

Ilex paraguariensis A. St.-Hil (Aquifoliaceae), known as mate, is an abundant plant, native of South America, $20 \mathrm{~m}$ tall, with a dense crown, and very branched (Souza, 2009). After processing, its leaves are traditionally used in a regional tea known as mate in Argentina, Brazil, Paraguay, and Uruguay (Souza, 2009). I. paraguariensis is commercially important due to the presence of caffeine and theobromine, both recognized as having a stimulant effect in the nervous and cardiocirculatory systems (Castaldelli et al., 2011). The described pharmacological activities for I. paraguariensis leaf extracts include antioxidant, hypolipidemic (Gao et al., 2013; Messina et al., 2015), and hypoglycemic effects (Conceição et al., 2017). Besides that, Ilex theezans Mart. Ex Reissek (Aquifoliaceae), popularly known as caúna-herb, is commonly found in Southern Brazil (Souza, 2009). It is well known due to the physiological characteristics of its leaves as an adulterant of I. paraguariensis (Athayde et al., 1999). It is an evergreen tree, early secondary or late secondary species (Souza, 2009), 20-m tall and 70-cm diameter, on average (Athayde et al., 1999). Both the $I$. paraguariensis fruit extract and the I. theezans hydroacoholic leaf extracts have larvicidal effect against A. aegypti larvae (Busato et al., 2015; Knakiewicz et al., 2016).

Some studies showed that Ilex spp. leaves and fruit extracts kill $A$. aegypti larvae within a 24-h observational time (Busato et al., 2015; Knakiewicz et al., 2016). However, there are no studies in the current literature evaluating the effects of time on the bioinsecticide lethal activity. How long is long enough for the bioinsecticide to maintain its ability to kill? (Resende and Gama, 2006; Santos et al., 2007; Guirado and Bicudo, 2009). In this context, the lethal residual effect of B. thuringiensis var. israelensis, and leaf and fruit extracts of I. theezans, and $I$. paraguariensis, respectively, against $A$. aegypti larvae were evaluated. Time would positively affect $A$. aegypti larvae survival due to decay of the lethal compounds, as a hypothesis, but the mortality caused by I. theezans was higher when compared to I. paraguariensis, due to the difference in physical and chemical characteristics.

\section{Material and Methods}

\section{Animal source}

The A. aegypti larvae used in this experiment were provided by Laboratório de Entomologia Ecológica (LABENT-Eco). A filter paper 
holding about 300 eggs was placed in a plastic tray $(30 \times 20 \mathrm{~cm})$ holding $1 \mathrm{~L}$ of tap dechlorinated water. After hatching, the larvae were distributed among three plastic trays of equal size and fed with $2 \mathrm{~g}$ of fish food. The mosquito larvae were raised for about 4-5 days until reaching $3^{\text {rd }}$ and $4^{\text {th }}$ instars.

\section{Plant source and extract preparation}

Fruits and leaves were obtained from native trees located at the Marechal Bormann district $\left(27^{\circ} 19^{\prime} 05^{\prime \prime}\right.$; $\left.52^{\circ} 65^{\prime} 11^{\prime \prime} \mathrm{W}\right)$, Chapecó City (Santa Catarina State), in December 2016. Plant parts were dehydrated at room temperature $\left( \pm 20^{\circ} \mathrm{C}\right)$, pulverized in a knife mill (Cielamb ${ }^{\circledast}$, CE 430), and stored away from light and humidity. Plant extracts were prepared according to Busato et al. (2015) and Knakiewicz et al. (2016). Samples of $20 \mathrm{~g}$ of $I$. paraguariensis dehydrated fruits and I. theezans leaves were used. Both samples were extracted by turbolysis, using $200 \mathrm{~mL}$ of distilled and deionized water and a hydroalcoholic solution (90\% ethanol; $200 \mathrm{~mL}$ ) as solvent, respectively (ANVISA, 2019). The extracts were filtered in Büchner funnel, concentrated by rotavapor under reduced pressure, lyophilized, weighed, identified, and stored in a freezer at $-20^{\circ} \mathrm{C}$. Hydroalcoholic and aqueous extracts were prepared using I. theezans and I. paraguariensis leaves and fruits, respectively. Leaves at a concentration of $1,000 \mu \mathrm{g} / \mathrm{mL}$ were used, and fruits were diluted to $2,000 \mu \mathrm{g} / \mathrm{mL}$. B. thuringiensis var. israelensis (Bti), strain $\mathrm{WG}^{\circledR}$, was used in a concentration of $0.004 \mathrm{~g} / \mathrm{L}$, the lethal dose specified by the manufacturer.

\section{Experimental microcosms and design}

Plastic cups of $300 \mathrm{~mL}$ with $100 \mathrm{~mL}$ of dechlorinated water plus the treatment proposed were adopted. In each individual sample, $203^{\text {rd }}$ and $4^{\text {th }}$ instar A. aegypti larvae were added. Each container was covered with a mosquito net held by a rubber elastic band. Tests for the effects of Bti spores; I. theezans, and I. paraguariensis leaves and fruits, respectively, were conducted; clean aged water (control) on the A. aegypti larval mortality after seven days of exposure was also performed (Nakazawa et al., 2020). Before running the mortality test, each experimental treatment aged from one to eight weeks. Each week was considered as one age block with each treatment replicated six times. With this experimental design, the independence of each set of treatments was assured. The aged treatments were used to test for larval survival in each experimental week. At the end of the $7^{\text {th }}$ day, larval survival was recorded, with both pupae and emerged adults being considered as survivals. The experiment was performed for eight weeks (56 days) and carried out between April and May 2017 at the LABENT-Eco mosquito colony room, under controlled conditions of temperature and photoperiod $\left(27 \pm 3^{\circ} \mathrm{C}, 12 \mathrm{~h} \mathrm{D}: \mathrm{L}\right)$.

\section{Statistics}

Since both negative (Bti) and positive (tap water) control survival rates were $0.16 \%$ and $100 \%$, respectively, the data were analyzed in both ways, with (complete model) and without (simple model) these two categories. In order to evaluate differences in the percentage of larval mortality (response variable) between simple (I. paraguariensis and I. theezans) and the complete models (only water, Bti spores, I. paraguariensis and I. theezans), regarding week (1 to 8) and week-treatment interaction (explicative variables), we used factorial GLM, with binomial correct to quasi-binomial (link = logit, test $=$ Chi-square) distributions (Crawley, 2007). All analyzed GLMs were corrected for cases of under- or overdispersion.

Differences among the categorical variables were assessed with a contrast analysis (Crawley, 2007). In this analysis (orthogonal), the dependent variables (different treatment and weeks) were ordered increasingly and tested pairwise (with the closest values); sequentially, adding to the model values with no differences and testing with the next values in a stepwise model simplification (for more details see also Chapter 9 of Crawley, 2007). All analyses were performed using the R program (Venables et al., 2019).

\section{Results}

The A. aegypti larval mortality was not affected by the water age (positive control). In contrast, the Bti resulted in the death of all the larvae until the age of seven weeks, with only $6.6 \%$ of larvae alive on the age of eight weeks (negative control). In this way, due to these extreme results in controls $(0 \%$ of mortality in the positive control and $100 \%$ of mortality in the negative control), mortality data were analyzed only between treatments (I. paraguariensis and I. theezans).

Larval mortality was significantly different between treatments (I. paraguariensis and I. theezans), weeks ( 1 to 8 ), and interaction factors (week:treatment) for both GLMs models (with and without positive and negative controls; Table 1). The highest larval mortality was found in the Bti treatment (negative control), followed by I. theezans, I. paraguariensis, and positive control (Table 1; Figure 1A). In addition, the I. theezans hydroalcoholic leaf extract, regardless of extract's age, killed significantly more $A$. aegypti larvae than the aqueous I. paraguariensis fruit extract (Table 1; Figure 1B).

A positive relationship between the survival of the larvae and the plant extract age was observed. In general, both I. paraguariensis and I. theezans killed less (mainly after seven weeks) mosquito larvae as the plant extracts aged (Figure 2). A higher significant larval mortality was found in week 1 , followed by weeks 2 and 3, weeks 4 and 6, week 5 , and weeks 7 and 8 (Figures $1 \mathrm{~B}$ and 1C).

Residual deviance (estimate of the variance of the tested variables) in GLM with positive and negative controls, showed that differences in all treatments (74\%) was the main responsible for larval mortality, followed by extracts' age (18\%; Table 1). On the other hand, residual deviance in GLM, without positive and negative controls, showed that differences between all weeks (68\%) was the main responsible for larval mortality, followed by treatments (6\%; Table 1$)$. 


\section{Discussion}

Transformation of the larvicide effect into food resource over time

I. theezans and I. paraguariensis extracts are promising against mosquito larvae (if applied and monitored in the first weeks). The potential of using these plant extracts as larvicides for A. aegypti may be an advantage, since they are natural extracts and do not leave toxic waste in the environment. These extracts are an abundant and accessible alternative in Southern Brazil, where A. aegypti infestation and dengue cases have been observed in the last decade (Busato et al., 2015). However, extracts' age should be considered; the main objective of the present study is not to discourage the use of such alternative method, but to warn about the importance of extract aging before using it for mosquito-control purposes. Better results may also be obtained with the development of additional studies, evaluating the larvicidal activity of pure compounds isolated from these plants. Furthermore, better results might be obtained by evaluating if there is a supporting effect of more than one active principle with larvicidal action against $A$. aegypti.

Plant extracts may degrade as time goes by, and these organic compounds with previous larvicidal activity may become food for $A$. aegypti larvae (explaining the residual deviance percentage in GLMs models). The transformation of larvicides into food probably took place, especially in those treatments with seven- and eight-weeks old plant extracts, which presented the highest survival rate. Therefore, the age of plant extract should be considered (Albeny-Simões et al., 2015).

\section{Aedes aegypti larval mortality between plant extracts}

Plant extract age plays an important role on mosquito larvae mortality (mainly with positive and negative controls). Despite the plant species, plant parts, and extraction method, mosquito larval mortality decreases with the aging of plant extracts. However, the extracts tested were highly efficient in the first weeks of the experiment (high mortality). The higher larval mortality found in the I. theezans extracts can be partially explained by the use of solvents during the extraction process (Lee and Houghton, 2005). The hydroalcoholic extraction method used to obtain the I. theezans extracts removed low polarity chemical constituents from plant tissues, and these molecules have a higher ability to penetrate mosquitoes' larvae cells and modify their metabolic activities.

On the other hand, aqueous extraction, used for the I. paraguariensis fruits, preferentially removes high-polarity chemical compounds, which are not able to easily penetrate such cells (Lee and Houghton, 2005). Moreover, the susceptibility of A. aegypti larvae to I. theezans may be explained by the presence of secondary metabolites of the coumarin class and absence of alkaloids when compared to I. paraguariensis (Valduga et al., 1997). Coumarins are part of the secondary metabolism of several plants, being well known for presenting insecticidal activities, acting as a repellent of adult insects, preventing oviposition, impairing feeding and growth, promoting morphogenetic and hormonal system alterations, sexual behavior changes, and adult sterilization, among other effects (Dietrich et al., 2011). Furthermore, I. paraguariensis has a higher content of caffeoyl derivatives and flavonoids than I. theezans. Flavonoids are recognized for their potent larvicidal activity, which may partially explain the results obtained herein (Filip et al., 2001; Garcez et al., 2013). In raw plant extracts, the active constituents are usually found in small concentrations (Krinski et al., 2014).

\section{Larvae mortality and extract age of Aedes aegypti}

In both $I$. theezans and I. paraguariensis, the mortality of A. aegypti larvae exposed to one-week plant extracts was $100 \%$.

Table 1 - Generalized linear models (GLM), degrees of freedom (Df), Residual Deviance (total and in), and $p$ values, comparing the percentage of Aedes aegypti larvae mortality after exposure to treatments (water control, Bacillus thuringiensis israelensis - Bti, hydroalcoholic dried leaves extract of Ilex theezans, and aqueous Ilex paraguariensis fruits extract), time (8 weeks) and interaction among treatments and weeks, under laboratory conditions.

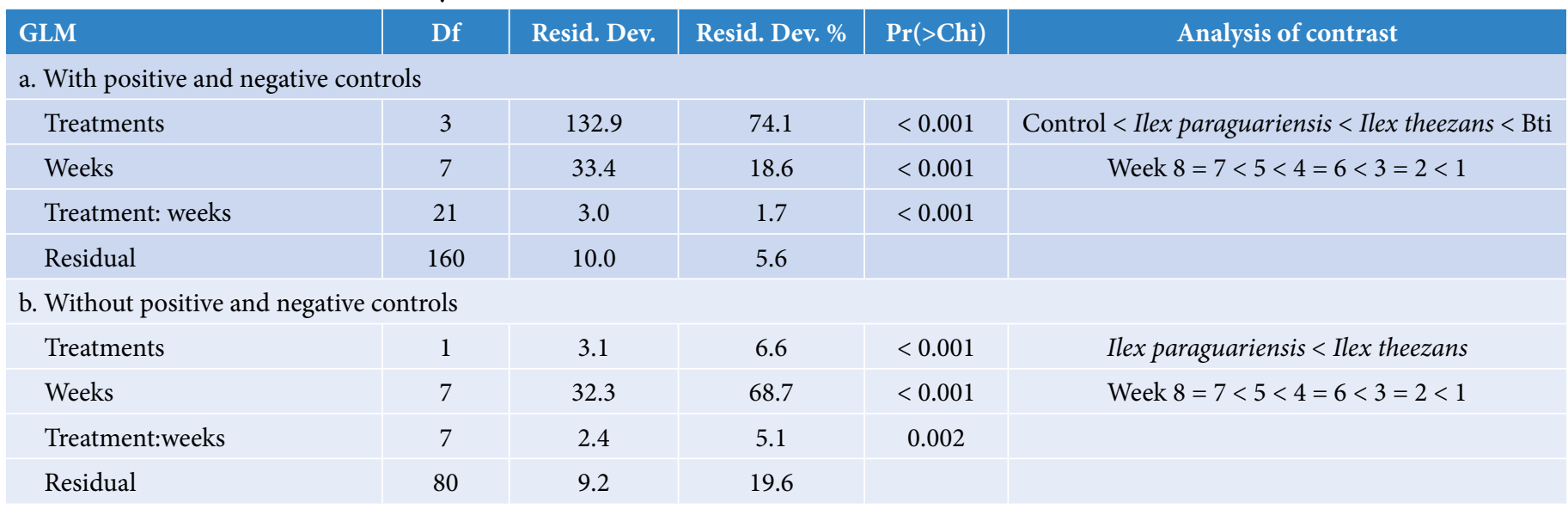


However, the plant extracts for both species reduced the mortality of mosquito larvae as the plant extracts aged. These results pointed out the need for carefully selecting the right age for an Ilex spp. plant extract before using it to control mosquito larvae.

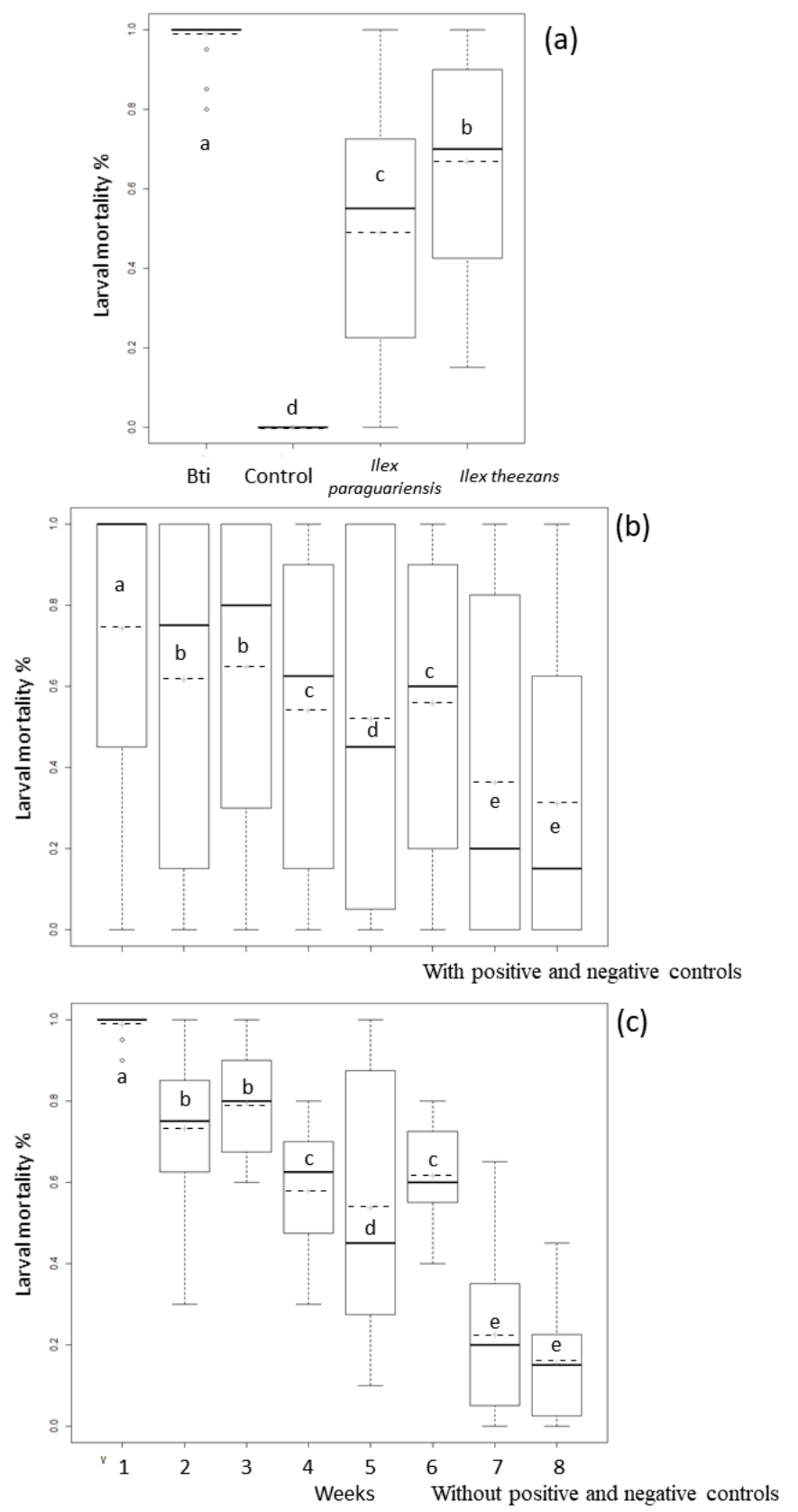

Figure 1 - (A) Aedes aegypti larvae mortality among treatments, (B) sample weeks with positive and negative controls, and (C) sample weeks without positive and negative controls among them ${ }^{*}$. *Different letters ("a", "b", "c", "d", and "e") indicate significant differences. Boxes represent the quartiles, bold line represents the median, horizontal dashed line represents the mean, vertical dashed line represents the upper and lower limits, and circles represent the outliers.
This is especially true since a product is considered efficient for pest population control when it reduces individuals above $80 \%$, otherwise resistance genes are selected (Jagadeesan et al., 2016).

In addition, besides the decaying of lethal chemical compounds which were toxic for mosquito larvae on the first week, as time goes by, the organic compounds present on the plant extracts may act as a useful food source for mosquito larvae. In this way, since organic compounds are well known for being an important component of several larval habitats, forming the basis of many food webs (Merritt et al., 1992; Moore et al., 2004), microorganisms such as bacteria play an important role in the cycling and breaking of large organic molecules (Sinsabaugh and Linkins, 1990). Therefore, microorganisms may act making them more easily absorbed by aquatic organisms, such as mosquito larvae, especially those belonging to the Culicidae family (Merritt et al., 1992). As a result, decomposing microbial communities present a relevant contribution to the diet of culicid larvae, being ingested with the organic remains over time (Merritt et al., 1992; Cochran-Stafira; Von Ende, 1998; Kaufman et al., 1999; Eisenberg et al., 2000).

The Bti of the present study resulted in $93.4 \%$ mortality in the eight-week solution. The residual effect described in the technical manual of the manufacturer is 30 days. Moreover, the values obtained herein were much higher than those described in the literature, with a lethality of $100 \%$ for 49 days and $6.6 \%$ of larval survival in up to 56 days. In this way, evaluating the effectiveness of the products that are already being used by state programs to control and combat $A$. aegypti could be performed. The use of the methodology without water renewal in the experiment resulted in a longer residual effect. Thus, not evaluating the effect of this renewal in reducing the residual effect of larvicidal substances (Pontes et al., 2005). Other studies in the field should encourage this water renewal by constantly emptying and replacing water, which would probably contribute to the reduction of the residual effect for all treatments tested.

\section{Conclusions}

The present study emphasized the need to implement alternative methods for vector control, since they represent a long-term risk. Furthermore, in the short term, it reported potential alternative pathways for mosquito-population control using natural products originated from the native flora. The plants presented a high larvicidal effect against A. aegypti, contributing to the maintenance of the quality of life and well-being of the population, since they are easily accessed by the local populations, reducing public expenditure with vector control and treatment of confirmed cases of dengue. Finally, time positively affected the survival of A. aegypti larvae due to the decay of lethal compounds from plant extracts, corroborating our first hypothesis. We also found that mortality by $B$. thuringiensis var. israelensis was constant throughout the experimental period and A. aegypti larvae survival was lower in the treatments with plant extracts than with $B$. thuringiensis var. israelensis. High mortality was observed in extracts of $I$. theezans compared to $I$. 


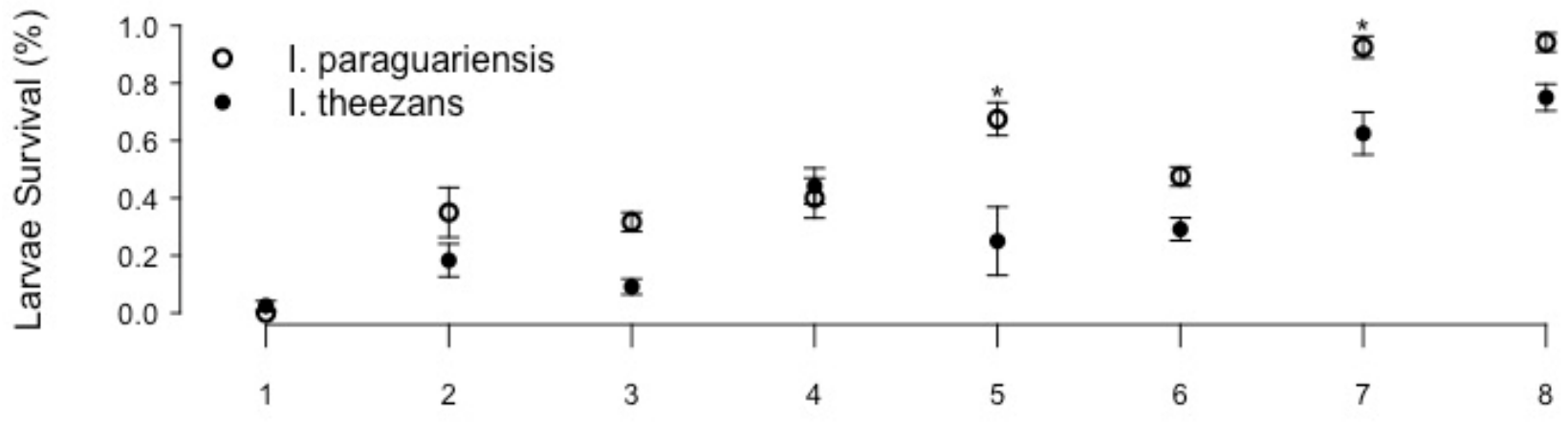

\section{Weeks}

Figure 2 - A. aegypti larvae survival's mean as a function of plant extracts' age. Extracts' age are represented by weeks. The circles represent, aqueous I. paraguariensis fruits extract (open) and I. theezans hydroalcoholic leaves extract (closed).

*Significant statistical difference between I. paraguariensis and I. theezans affecting larvae survival.

paraguariensis, corroborating our second hypothesis. The strongest residual effect of $I$. theezans was probably due to the presence of chemicals on their leaves, such as coumarins, hemolytic saponins, and cyanogenic glucosides, which were absent in I. paraguariensis.

\section{Acknowledgements}

The authors thank Unochapecó for the availability to use the laboratories and for the Research Program for the Brazilian Unified Health System.

\section{Contribution of authors:}

Cozzer, G.D.: Investigation, Data Curation, Writing - original draft. Rezende, R.S.: Software, Formal Analysis, Writing - review \& editing. Lutinski, J.A.: Conceptualization, Methodology, Supervision, Writing - review \& editing. Roman Júnior, W.A.: Methodology, Writing - review \& editing. Busato, M.A.: Writing - review \& editing. Simões, D.A.: Supervision, Formal Analysis, Funding Acquisition, Writing - review \& editing.

\section{References}

Agência Nacional de Vigilância Sanitária (ANVISA). 2019. Farmacopeia Brasileira. 6. ed. Anvisa, Brasília, 874 pp.

Albeny-Simões, D.; Murrell, E. G.; Vilela, E. F.; Juliano, S. A., 2015. A multifaceted trophic cascade in a detritus-based system. Ecosphere, v. 6, (3), 32. https://doi.org/10.1890/es14-00365.1.

Apaire-Marchais, V.; Ogliastro, M.; Chandre, F.; Pennetier, C.; Raymond, V.; Lapied, B., 2016. Virus and calcium: an unexpected tandem to optimize insecticide efficacy. Environmental Microbiology Reports, v. 8, (2), 168-178. https://doi.org/10.1111/1758-2229.12377.

Araújo, A.J.; Lima, J.S.; Moreira, J.C.; Jacob, S.C.; Soares, M.O.; Monteiro, M.C.M.; Amaral, A.M.; Kubota, A.; Meyer, A.; Cosenza, C.A.; Neves, C.; Markowitz, S., 2007. Exposição múltipla a agrotóxicos e efeitos à saúde: estudo transversal em amostra de 102 trabalhadores rurais, Nova Friburgo, RJ. Ciência e Saúde Coletiva, v. 12, (1), 115-130. http://dx.doi.org/10.1590/S141381232007000100015 .

Athayde, M.L.; Schenkel, E.P.; Gosmann, G.; Guillaume, D., 1999.

Triterpenoids from the leaves of ilex theezans martius ex reiss. Acta Farmaceutica Bonaerense, v. 18, (1), 49-52.
Baskar, K.; Sudha, V.; Nattudurai, G.; Ignacimuthu, S.; Duraipandiyan, V.; Jayakumar, M.; Al-Dhabi, N.; Benelli, G., 2018. Larvicidal and repellent activity of the essential oil from atalantia monophylla on three mosquito vectors of public health importance, with limited impact on non-target zebra fish. Physiological And Molecular Plant Pathology, v. 101, 197-201. https://doi. org/10.1016/j.pmpp.2017.03.002.

Brasil. 2001. Ministério da Saúde. Dengue, instruções para pessoal de combate ao vetor. 3. Ed. Ministério da Saúde, Brasília.

Brasil. 2002. Ministério da Saúde. Programa Nacional de Controle da Dengue. Ministério da Saúde, Brasília.

Busato, M.A.; Vitorello, J.; Lutinski, J.A.; Magro, J.D.; Scapinello, J., 2015. Potencial larvicida de melia azedarach 1. e ilex paraguariensis St. Hil. No controle de Aedes aegypti (Linnaeus, 1762) (Diptera: Culicidae). Ciência e Natura, v. 37, (2), 277-282. http://dx.doi.org/10.5902/2179460X15922.

Castaldelli, A.P.A.; Vieira, L.P.; Przygodda, F.; Martins, Z.N.; Padoin, M.J., 2011. Efeito da erva mate ( Ilex paraguariensis a . st . -hill) no comportamento e fisiologia de ratos Wistar. Revista Brasileira de Biociências, v. 9, (4), 514-519. 
Cochran-Stafira, D.L.; Von Ende, C.N., 1998. Integrating bacteria into food webs: studies with Sarracenia purpurea inquilines. Ecology, v. 79, (3), 880-898. https://doi.org/10.1890/0012-9658(1998)079[0880:IBIFWS]2.0.CO;2.

Coelho, W.M.D.; Coêlho, J.C.A.; Bresciani, K.D.S.; Buzetti, W.A.S., 2017. Biological control of Anopheles darlingi, Aedes aegypti and Culex quinquefasciatus larvae using shrimps. Parasite Epidemiology and Control, v. 2, (3), p. 91-96. https://dx.doi.org/10.1016\%2Fj.parepi.2017.05.002.

Conceição, E.P.S.; Kaezer, A.R.; Peixoto-Silva, N.; Felzenszwalb, I.; Oliveira, E.; Moura, E.G.; Lisboa, P.C., 2017. Effects of Ilex paraguariensis (yerba mate) on the hypothalamic signalling of insulin and leptin and liver dysfunction in adult rats overfed during lactation. Journal of Developmental Origins of Health and Disease, v. 8, (1), 123-132. https://doi.org/10.1017/s2040174416000519.

Crawley, M.J. 2007. The R Book. John Wiley \& Sons Inc., Chichester.

Crivelenti, L.Z.; Guilherme, L.C.; Morelli, S.; Borin, S., 2010. Toxicidade do inseticida organofosforado Abate ${ }^{\circledR}$ em alevinos de poecilia reticulata. Journal of the Brazilian Society of Ecotoxicology, v. 5, (2-3), 1-13.

Dietrich, F.; Strohschoen, A.A.G.; Schultz, G.; Sebben, A.D.; Rempel, C., 2011. Utilização de inseticidas botânicos na agricultura orgânica de arroio do meio / RS. Revista Brasileira de Agrociências, v. 17, (2-4), 251-255. https://doi. org/10.18539/cast.v17i2.2056

Eisenberg, J.N.S.; Washburn, J.O.; Schreiber, S.J., 2000. Generalist feeding behaviors of Aedes sierrensis larvae and their effects on protozoan populations. Ecology, v. 81, (4), 921-935. https://doi.org/10.1890/00129658(2000)081[0921:GFBOAS]2.0.CO;2.

Filip, R.; López, P.; Giberti, G.; Coussio, J.; Ferraro, G., 2001. Phenolic compounds in seven south ameican ilex species. Fitoterapia, v. 72, (7), 774778. https://doi.org/10.1016/s0367-326x(01)00331-8.

Gao, H.; Liu, Z.; Wan, W.; Qu, X.; Chen, M., 2013. Aqueous extract of yerba mate tea lowers atherosclerotic risk factors in a rat hyperlipidemia model. Phytotherapy Research, v. 27, (8), 1225-1231. https://doi.org/10.1002/ptr.4856.

Garcez, W.S.; Garcez, F.R.; Silva, L.M.G.E.; Sarmento, U.C., 2013. Substâncias de origem vegetal com atividade larvicida contra Aedes aegypti. Rev. Virtual Quim. v. 5, (3), 363-393. http://dx.doi.org/10.5935/1984-6835.20130034.

Gomes, P.R.B.; Silva, A.L.S.; Pinheiro, H.A.; Carvalho, L.L.; Lima, H.S.; Silva, E.F.; Silva, R.P.; Louzeiro, C.H.; Oliveira, M.B.; Filho, V.E.M., 2016. Avaliação da atividade larvicida do óleo essencial do Zingiber officinale roscoe (gengibre) frente ao mosquito Aedes aegypti. Revista Brasileira de Plantas Medicinais, v. 18, (2 Suppl. 1), 597-604. https://doi.org/10.1590/1983-084x/15_214.

Govindarajan, M.; Rajeswary, M.; Senthilmurugan, S.; Vijayan, P.; Alharbi, N.S.; Kadaikunnan, S.; Khaled, J.M.; Benelli, G., 2018. Larvicidal activity of the essential oil from Amomum subulatum roxb. (zingiberaceae) against Anopheles subpictus, Aedes albopictus and Culex tritaeniorhynchus (diptera: culicidae), and non-target impact on four mosquito natural enemies. Physiological And Molecular Plant Pathology, v. 101, 219-224. https://doi. org/10.1016/j.pmpp.2017.01.003.

Guarda, C.; Lutinski, J.A.; Roman-Junior, W.A.; Busato, M.A., 2016. Atividade larvicida de produtos naturais e avaliação da susceptibilidade ao inseticida temefós no controle do Aedes aegypti (Diptera: Culicidae). Interciência, v. 41, (4), 243-247.

Guirado, M.M.; Bicudo, H.E.M.C., 2009. Alguns aspectos do controle populacional e da resistência a inseticidas em Aedes aegypti (Diptera, culicidae). Instituto de Biociências, Letras e Ciências Exatas, v. 6, (64), 5-14.

Jagadeesan, R.; Collins, P..; Nayak, M.K.; Schlipalius, D.I.; Ebert, P.R., 2016. Genetic characterization of field-evolved resistance to phosphine in the rusty grain beetle, Cryptolestes ferrugineus (laemophloeidae: coleoptera). Pesticide Biochemistry and Physiology, v. 127, 67-75. https://doi.org/10.1016/j.pestbp.2015.09.008.
Kaufman, M.G.; Walker, E.D.; Smith, T.W.; Merritt, R.W.; Klug, M.J., 1999. Effects of larval mosquitoes (Aedes triseriatus) and stemflow on microbial community dynamics in container habitats. Applied and Environmental Microbiology, v. 65, (6), 2661-2673. https://doi.org/10.1128/AEM.65.6.2661-2673.1999.

Knakiewicz, A.C.; Lutinski, J.A.; Guarda, C.; Paris, A.; Belotti, A.; Busato, M.A.; Roman Junior, W.A.; Simões, D.A., 2016. Larval susceptibility of Aedes aegypti (1.) (diptera: culicidae) to extracts of ilex paraguariensis and ilex theezans. Revista Brasileira de Ciências Ambientais (online), (42), 113-120. https://doi. org/10.5327/Z2176-947820160177.

Krinski, D.; Massaroli, A.; Machado, M., 2014. Potencial inseticida de plantas da família Annonaceae. Revista Brasileira de Fruticultura, v. 36, (spe. no.), 225 242. https://doi.org/10.1590/S0100-29452014000500027.

Lee, C.C.; Houghton, P., 2005. Cytotoxicity of plants from malaysia and thailand used traditionally to treat cancer. Journal of Ethnopharmacology, v. 100, (3), 237-243. https://doi.org/10.1016/j.jep.2005.01.064.

Liu, N., 2015. Insecticide resistance in mosquitoes: impact, mechanisms, and research directions. Annual Review of Entomology, v. 60, 537-559. https://doi. org/10.1146/annurev-ento-010814-020828.

Lopes, N.; Nozawa, C.; Linhares, R.E.C., 2014. Características gerais e epidemiologia dos arbovírus emergentes no Brasil. Revista Pan-Amazônica de Saúde, v. 5, (3), 55-64.

Merritt, R.W.; Dadd, R.H.; Walker, E.D., 1992. Feeding behavior, natural food, and nutritional relationships of larval mosquitos. Annual Review of Entomology, v. 37, 349-376. https://doi.org/10.1146/annurev.en.37.010192.002025.

Messina, D.; Soto, C.; Méndez, A.; Corte, C.; Kemnitz, M.; Avena, V.; Del Balzo, D.; Elizalde, R.P., 2015. Efecto hipolipemiante del consumo de mate en individuos dislipidémicos. Nutricion Hospitalaria, v. 31, (5), 2131-2139. https://doi.org/10.3305/nh.2015.31.5.8386.

Moore, M.V.; Berlow, E.L.; Coleman, D.C.; Ruiter, P.C.; Dong, Q.; Hastings, A.; Johnson, N.C.; McCann, K.S.; Melville, K.; Morin, P.J.; Nadelhoffer, K.; Rosemond, A.D.; Post, D. M.; Sabo, J.L.; Scow, K.M.; Vanni, M.J.; Wall, D.H., 2004. Detritus, trophic dynamics and biodiversity. Ecology Letters, v. 7, (7), p. 584-600. https://doi.org/10.1111/j.1461-0248.2004.00606.x.

Nakazawa, M.M.; Araújo, A.P.; Melo-Santos, M.A.V.; Oliveira, C.M.F.; SilvaFilha, M.H.N.L., 2020. Efficacy and persistence of Bacillus thuringiensis svar. israelensis (bti) and pyriproxyfen-based products in artificial breeding sites colonized with susceptible or bti-exposed Aedes aegypti larvae. Biological Control, v. 151, 104400. https://doi.org/10.1016/j.biocontrol.2020.104400.

Pontes, R.J.S.; Regazzi, A.C.F.; Lima, J.W.O.; Kerr-Pontes, L.R.S., 2005. Efeito residual de apresentações comerciais dos Larvicidas temefos e Bacillus thuringiensis israelensis sobre larvas de Aedes aegypti em recipientes com renovação de água. Revista da Sociedade Brasileira de Medicina Tropical, v. 38, (4), 316-321. https://doi.org/10.1590/S0037-86822005000400007.

Resende, M.C.; Gama, R.A., 2006. Persistência e eficácia do regulador de crescimento pyriproxyfen em condições de laboratório para Aedes aegypti. Revista da Sociedade Brasileira de Medicina Tropical, v. 39, (1), 72-75. https:// doi.org/10.1590/S0037-86822006000100014.

Rosa, C.S.; Veras, K.S.; Silva, P.R.; Lopes Neto, J.J.; Cardoso, H.L.M.; Alves, L.P.L.; Brito, M.C.A.; Amaral, F.M.M.; Maia, J.G.S.; Monteiro, O.S.; Moraes, D.F.C., 2016. Composição química e toxicidade frente Aedes aegypti l. e Artemia salina leach do óleo essencial das folhas de Myrcia sylvatica (G. Mey.) Dc. Revista Brasileira de Plantas Medicinais, v. 18, (1), 19-26.

Santos, R.L.C.; Fayal, A.S.; Aguiar, A.E.F.; Vieira, D.B.R.; Póvoa, M.M., 2007. Evaluation of the residual effect of pyrethroids on anopheles in the Brazilian Amazon. Revista de Saúde Pública, v. 41, (2), 276-283. https://doi.org/10.1590/ S0034-89102007000200015. 
Sinsabaugh, R.L.; Linkins, A.E., 1990. Enzymic and chemical analysis of particulate organic matter from a boreal river. Freshwater Biology, v. 23, (2), 301-309. https://doi.org/10.1111/j.1365-2427.1990.tb00273.x.

Soares-Da-Silva, J.; Queirós, S.G.; Aguiar, J.S.; Viana, J.L.; Neta, M.R.A.V.; Silva, M.C.; Pinheiro, V.C.S.; Polanczyk, R.A.; Carvalho-Zilse, G.A.; Tadei, W.P., 2017. Molecular characterization of the gene profile of Bacillus thuringiensis berliner isolated from brazilian ecosystems and showing pathogenic activity against mosquito larvae of medical importance. Acta Tropica, v. 176, 197-205. https://doi.org/10.1016/j.actatropica.2017.08.006.

Souza, M.F.F., 2009. Chá mate (Ilex paraguariensis): compostos bioativos e relação com atividade biológica. Dissertation, mastering in Nutrition, Faculdade de Saúde Pública, Universidade de São Paulo, São Paulo.

Sun, Y.; Dong, Y.; Li, J.; Lai, Z.; Hao, Y.; Liu, P.; Chen, X.; Gu, J., 2019. Development of large-scale mosquito densovirus production by in vivo methods. Parasites and Vectors, v. 12, (1), 255. https://doi.org/10.1186/s13071019-3509-5.
Tahir, U.; Khan, U. H.; Zubair, M.S.; Bahar-e-Mustafa, 2015. Wolbachia pipientis: a potential candidate for combating and eradicating dengue epidemics in pakistan. Asian Pacific Journal of Tropical Medicine, v. 8, (12), 989-998. https://doi.org/10.1016/j.apjtm.2015.11.012.

Valduga, E.; Freitas, R.J.S.; Reissmann, C.B.; Nakashima, T., 1997. Caracterização química da folha de Ilex paraguariensis st. hil. (erva-mate) e de outras espécies utilizadas na adulteração do mate. Boletim do Centro de Pesquisa de Processamento de Alimentos, v. 15, n. 1, 25-36.

Venables, W.N.; Smith, D.M.; Team, R.C., 2019. An Introduction To R. N. Venables E D. M. Smith Copyright, v. 2, 105.

Weaver, S.C.; Reisen, W.K., 2010. Present and future arboviral threats. Antiviral Research, v. 85, (2), 328-345. https://doi.org/10.1016/j.antiviral.2009.10.008.

Zara, A.L.S.A.; Santos, S.M.; Fernandes-Oliveira, E.S.; Carvalho, R.G.; Coelho, G.E., 2016. Estratégias de controle do Aedes aegypti: uma revisão. Epidemiologia e Serviços de Saúde, v. 25, (2), p. 391-404. https://doi. org/10.5123/s1679-49742016000200017. 